\title{
RAVETTI, Graciela e ARBEX, Márcia (organizadoras). Performance, exílio, fronteiras, errâncias territoriais e textuais. Bello Horizonte: Departamento de Letras Românicas, Poslit, FALE/UFMG, 2002. 320 p. ill.
}

\section{Sara Rojo**}

Fazer uma resenha da obra Performance, exílio, fronteiras, errâncias territoriais e textuais das organizadoras Graciela Ravetti e Márcia Arbex não é uma tarefa fácil, uma vez que não apenas se cruzam em seus textos diversas problemáticas, como, também, são debatidos conceitos polêmicos, tais como: arquivo/repertório (Taylor), escrita performática (Ravetti), oralitura (Martins), textos performáticos (Rojo), tradução/cópia (Alexandre), etnicidade luso-americana (Ferreira), inscrição corporal do corpo (Almeida), lógica do bimen (Magnabosco), enunciação feminina (Diniz), estrangeiridade (Cury), colagem $=$ citação $=$ intertexto (Arbex), corpo objeto (Casa Nova), paródia (Machado), instância do leitor (Mello), lingua em estado dialetal puro (Cohen), teatralização da cavalaria (Cunha), reconstrução bistórica de uma obra (Nardelli).

\footnotetext{
- Professora do Departamento de Letras Românicas da Faculdade de Letras da UFMG.
} 
Diante destas numerosas problemáticas, seria pertinente que se colocasse uma questão como esta: qual seria o fio condutor que permitiria ao leitor perceber esse texto como uma obra única? A chave para encontrá-lo encontra-se na introdução. Este fio diretor é inserido pelas organizadoras quando propõem o conceito de fronteira:

Toma-se, aqui, o conceito no seu sentido mais ambivalente. Aquilo que separa também indica contigüidade e, queiramos ou não, funda espaços concomitantes, estabelece distinções (...) Os textos deste livro trabalham, portanto, com articuladores móveis, com o intuito de estabelecer contatos com a história, a política, a cultura, as artes, a sociedade e os sujeitos (RAVETTI/ ARBEX, 2002: 9)

Tomando como pressuposto que o ponto de encontro das teorizações estabelece-se nas fronteiras, podemos passar a refletir sobre o caráter polêmico de alguns dos conceitos enunciados e na relação com esse 'estar nas fronteiras'. Estes conceitos seriam:

O conceito de arquivo/repertório nos leva ao campo da história, pois, enquanto o arquivo se constrói no documento, no texto escrito, o repertório tem que dar conta da multiplicidade de textos que se registram na memória do povo, na práxis espetacular e em outras áreas.

Oficialmente, a história tem sido entendida como a letra escrita, deixando de fora todas as práticas que não se encaixavam nesse percurso. Dessa maneira, a hegemonia foi estabelecida pelo logos ocidental, cerceando culturas e estruturas que não têm espaço dentro desse conceito. Esta reflexão dialoga, entre outros, com o conceito de oralitura e constrói um saber a partir das práxis performáticas. Este saber 
impulsiona, direciona e conduz o leitor ou espectador a reagir na procura do sentido da sua existência.

É essa, para mim, a discussão fundamental que permeia os textos da primeira parte, intitulada "Textos em performance".

Lembramos, ainda, do conceito do "outro" expressado no corpo das mulheres, na enunciação das mesmas, na estrangeiridade, na etnicidade, conceito que constrói a segunda parte da obra: "Gênero, etnia: saberes em trânsito". É, esta, uma problemática extremamente polêmica na medida em que, hoje, entendemos, no plano da teoria, o sujeito como diferenciado, como portador de uma diversidade, enquanto que no plano da prática, vivemos um mundo globalizado, que tende, gostemos ou não, à homogeneização dentro do padrão masculino, branco e ocidental. Desta maneira, marcar as diferenças é ainda uma necessidade num mundo que vem se preocupando e discutindo sobre elas, mas que, na realidade, não as vivencia.

A terceira parte da obra, "Escrituras lúdicas: estratégias e análises", lida com a abrangência, surgida nestas últimas décadas, do conceito de texto, e com a interferência de discursos e disciplinas no construto do produto artístico. Contaminação e bricolagem são a constante em diversas obras deste período. Acreditamos que o sujeito criador necessita de todas as linguagens semióticas para dar conta de espaços nos quais a imagem, a letra e as diversas culturas se misturam. Tecnologia, resgate de práticas populares e corpo humano formam uma rede, constantemente refeita de diversas maneiras.

A quarta parte, "Línguas românicas: história, documentação e retórica", nos leva à origem das obras, das enunciaçōes, das próprias línguas. Sem esse retorno é impossível qualquer reescrita da história, ou melhor, das histórias. Este capítulo dialoga com o primeiro, no qual se debatiam os conceitos de arquivo e repertório na medida em que ambos refletem a história ou as 
histórias. Qual é o estágio atual das línguas românicas menos usadas? Que sucede com a enunciação das mulheres num determinado período, como o medieval? Qual é o percurso de uma obra? Estas são algumas das questões que surgem deste capítulo.

Esta obra, utilizando diversas teorizações, insere-se nos debates atuais da cultura e dos diálogos que hoje estabelecem as obras artísticas.

Convido-os, pois, a percorrer suas páginas, e, a partir das reflexões e enunciações colocadas, propor soluções novas que incitem novos debates. 